\title{
Polymorphism of the glutathione S-transferase P1 gene (GST-PI) IN BREAST CARCINOMA
}

\author{
Mohamad Nidal Khabaz
}

Pathology Department, Faculty of Medicine, Rabigh Branch, King Abdulaziz University, Jeddah, Saudi Arabia

\begin{abstract}
Breast carcinoma is the most common cancer and cause of death among females worldwide, including Jordan. The risk factors for breast carcinoma are linked to DNA mutation and failure of DNA repair or detoxification systems. Identification of susceptibility factors that predispose individuals to breast carcinoma if they are exposed to particular environmental agents might give further insight into the etiology of this malignancy. The glutathione S-transferase (GST) enzyme family detoxifies carcinogenic compounds. Several genes that code for these enzymes are polymorphic, with particular genotypes previously shown to confer an increased carcinoma risk. The present study investigates GST-pi polymorphism in 100 -tissue samples previously diagnosed as breast carcinoma, and in 48 non-cancer age-matched breast tissues, using the restriction fragment length polymorphism (RFLP) method for the polymerase chain reaction (PCR) product. Among breast cancer cases, 58\%, 40\% and 2\% were homozygous (Ile/Ile), heterozygous (Ile/Val) and homozygous ( $\mathrm{Val} / \mathrm{Val}$ ) respectively. In the control group, $58 \%, 37.5 \%$ and $4.2 \%$ were homozygous (Ile/Ile), heterozygous (Ile/Val), and homozygous (Val/Val) respectively. Our results did not support the involvement of GST-pi gene polymorphism in susceptibility to breast carcinoma in the tested North Jordanian female population.
\end{abstract}

Key words: breast carcinoma, glutathione-S-transferase, polymorphism, susceptibility.

\section{Introduction}

Breast carcinoma, in 2007 , ranked first among cancers in the Jordanian female population and it accounted for $35.8 \%$ of all female cancers. The crude incidence rate for female breast carcinoma in Jordan was 29.6 per 100000 of the female population in 2007 , compared to 25.4 per 100000 in 2005 . Histopathological distribution of female breast carcinomas showed that $77.4 \%$ were infiltrating ductal carcinoma, $7.1 \%$ were lobular carcinoma, $1.8 \%$ were mixed ductal and lobular carcinoma, and the remainder were other types of morphology [1].

Identified risk factors of breast carcinoma explain only one third of the disease cases. These risk factors include age (breast carcinoma incidence increases in post-menopausal females), family history of the disease and several reproductive factors [2]. The disease occurs in both sporadic and hereditary forms, the latter accounting for about $10 \%$ of total cases [3]. The cause of breast carcinoma is generally unknown; however, it develops when there is loss of control over cells of the breast, which multiply rapidly because of both genetic and environmental factors [3]. Enzymes involved in the detoxification of carcinogenic compounds as well as DNA repair may play a role in the susceptibility to this and other forms of cancer. The effectiveness of the detoxifying properties of such enzymes is genetically determined [4]. Polymorphic genes that code for these enzymes may hence be involved in breast carcinoma susceptibility. 
The glutathione S-transferases (GSTs) comprise a supergene family of phase-2 enzymes that catalyze the detoxification of electrophilic compounds such as carcinogens and cytotoxic drugs by glutathione conjugation [5, 6]. In addition, they guard DNA from damage and adduct formation through conjugation. GSTs detoxify the products of oxidation process, carried out by phase 1 enzymes [7].

Glutathione S-transferase-pi is a major GST, which is expressed in both normal and tumor breast tissue $[8,9,10]$, and the GST-pi gene has been mapped to a small region of chromosome 11q. Polymorphisms in exon 5 (Ile105 Val) and exon 6 (Ala114 Val) of the GST-pi gene have been identified [11, 12], and both affected codons lie in close proximity to the hydrophobic binding site of GST-pi. Moreover, polymorphism is known to change the properties of the enzyme [7]. The $105 \mathrm{Val}$ variant has been demonstrated to have either lower or higher specific activity and affinity than that of 105Ile depending on the substrate, whereas the Ala $114 \mathrm{Val}$ polymorphism seems not to influence enzyme activity $[13,14]$.

Against this background, the possibility that GSTpi polymorphism may be involved in the pathogenesis of breast carcinoma has received great attention. Some epidemiological studies on the potential association between genetic polymorphisms of GST-pi and breast carcinoma have produced inconsistent results [15-18]. These studies consistently failed to detect an association between breast carcinoma and GST-pi polymorphism, and the results and conclusions have been highly variable. These inconsistencies might be partly due to differences in populations, and their exposure to factors of breast carcinoma development.

Table I. Pathologic and clinical data of patients with breast cancer

\begin{tabular}{lcc}
\hline \multicolumn{1}{c}{ Clinico-Pathological Factors } & $\begin{array}{c}\text { Number } \\
\text { OF Patients }\end{array}$ \\
\hline Patient age & $<50$ years & $34(34 \%)$ \\
\cline { 2 - 3 } & $>50$ years & $66(66 \%)$ \\
\hline \multirow{2}{*}{$\begin{array}{l}\text { Size of primary } \\
\text { tumor }\end{array}$} & $<1 \mathrm{~cm}$ & $6(6 \%)$ \\
\cline { 2 - 3 } & $1-3 \mathrm{~cm}$ & $40(40 \%)$ \\
\hline \multirow{2}{*}{$\begin{array}{l}\text { Regional lymph } \\
\text { nodes }\end{array}$} & positive & $18(18 \%)$ \\
\cline { 2 - 3 } $\begin{array}{l}\text { Histopathologic } \\
\text { type }\end{array}$ & negative & $82(82 \%)$ \\
\cline { 2 - 3 } & ductal carcinoma & $88(88 \%)$ \\
\cline { 2 - 3 } & lobular carcinoma & $6(6 \%)$ \\
\hline Grade & others & $6(6 \%)$ \\
\cline { 2 - 3 } & I & $10(10 \%)$ \\
\cline { 2 - 3 } & III & $50(40 \%)$ \\
\hline
\end{tabular}

The evidence regarding a possible association of GSTpi polymorphism with breast carcinoma is thus controversial and, in view of the high incidence of this tumor, requires clarification.

Based on these considerations, this issue was evaluated for the first time in breast carcinoma in a Jordanian female population employing a combination of methods. All cases were subjected to a polymerase chain reaction (PCR) based genotyping assay and immunohistochemistry staining. Our data show no involvement of this specific GST-pi gene polymorphism in susceptibility to breast carcinoma.

\section{Material and methods}

This study includes 100 samples of paraffin-embedded tissue blocks of female individuals previously diagnosed with breast carcinoma, and 48 samples of paraffin-embedded breast tissue with no history of cancer of any type as a control population. All samples and the clinical data including age group, type of carcinoma, size and grade of carcinoma were collected from the medical records and the Pathology Department at Jordan University of Science and Technology. All samples were stored at room temperature.

The median age of the cancer patients was 44.66 years (range, 20 to 75 years). Node involvement was detected in $18 \%$ of cases. The tumor size was $<1 \mathrm{~cm}$ in diameter in $6 \%$ of cases, $>1$ and $<3 \mathrm{~cm}$ in $40 \%$ of cases, and $>3 \mathrm{~cm}$ in $54 \%$ of cases. Tumor type was ductal in $88 \%$ of cases, lobular in $6 \%$, and of other types in $6 \%$. The distribution of histoprognostic grading was $10 \%$ for type I, $40 \%$ for type II, and $50 \%$ for type III (Table I).

The control population includes 20 fibroadenomas, 8 fibrocystic changes, 8 duct ectasias, 4 sclerosing adenosis, 4 hyperplasias, and 4 intraductal papillomas. The median age of the control group was 37.6 years (range, 20 to 56 years). The size of benign lesions ranged from 1 to $2 \mathrm{~cm}$ in diameter, which was obtained by open surgical biopsy due to the fear of hidden microscopic cancer.

\section{Immunohistochemistry (IHC)}

Sections of $4 \mu \mathrm{m}$ were cut from paraffin blocks (from representative tumor samples excluding lymph nodes and necrotic sections of the primary tumor and from specimens of the control group). All paraffin sections were mounted on coated slides and were dewaxed in xylene, rehydrated through a series of graded alcohol, placed in $10 \mathrm{mM}$ citrate buffer $(\mathrm{pH}$ 6.0) and submitted to heat retrieval for $6 \mathrm{~min}$. After heating, the slides were allowed to cool to room temperature and washed with phosphate-buffered saline (PBS). Endogenous peroxidase activity was blocked with $3 \%$ hydrogen peroxide in methanol for $5 \mathrm{~min}$. 
Serum-free protein block (Dako, Denmark) was used for $5 \mathrm{~min}$ in order to block nonspecific immunoreactions. Monoclonal antibody against GSTPi (Abnova, Taiwan) was diluted 1:50 in antibody diluent and was applied to all slides for $30 \mathrm{~min}$ at room temperature. Detection was performed using the Dako Envision Dual Link system (Dako, Denmark) according to the manufacturer's instructions. After that, slides were visualized using Dako liquid DAB (Dako, Denmark). Mayer's hematoxylin was applied as a counter stain. The positive control for GST-pi was a slide containing normal breast tissue run simultaneously with the samples. As a negative control, the primary antibodies were omitted. In addition, the tumor tissue was compared with the adjacent normal tissue as available. Tumors were considered positive for GSTpi if more than $1 \%$ of the neoplastic cells displayed a distinct brown staining. The slides were scanned and all cells were counted in a high power field. Images were photographed using a digital camera (Olympus model C-5060).

\section{DNA extraction}

DNA from $10 \mu \mathrm{m}$ sections of paraffin-embedded tissue blocks belonging to all cases (cancer and controls) was extracted with an EXTRAffin kit (Nanogen Advanced Diagnostics S.r.L., Buttigliera Alta, Italy) according to the manufacturer's instructions. The extraction product was stored at $-20^{\circ} \mathrm{C}$.

\section{Genotyping}

The polymorphism (Ile $105 \rightarrow$ Val) in the exon 5 Coding region of the GST-pi gene was detected by restriction fragment length polymorphism of PCR amplified fragments. Standard GST-pi primers (forward 5'- ACC CCA GGG CTC TAT GGG AA-3', and reverse 5'-TGA GGG CAC AAG AAG CCC CT-3') (Alpha DNA, Canada) were used for the amplification reactions and restriction enzyme corresponding to RFLP (Fermentas, Canada) for the digestion reactions.

PCR reactions were carried out in a 30- $\mu$ l volume containing about $5 \mu \mathrm{L}$ of genomic DNA template, PCR master mix $\left(200 \mu \mathrm{M}\right.$ each dNTP, $1.5 \mathrm{mM} \mathrm{MgCl}_{2}$, $1 \times$ PCR buffer $[50 \mathrm{mM} \mathrm{KCl}, 10 \mathrm{mM}$ Tris- $\mathrm{HCl}(\mathrm{pH}$ 8.3)] and 2 unit Taq DNA polymerase) (Promega, USA) and $200 \mathrm{ng}$ of each primer. After an initial denaturation step of $5 \mathrm{~min}$ at $95^{\circ} \mathrm{C}$, the samples were processed through 35 temperature cycles of $30 \mathrm{~s}$ at $94^{\circ} \mathrm{C}, 1$ minute at $59^{\circ} \mathrm{C}$, and 1 minute at $72^{\circ} \mathrm{C}$. After a final extension step of $72^{\circ} \mathrm{C}$ for $10 \mathrm{~min}$, the presence of successful amplification was confirmed by electrophoreses on $2 \%$ agarose gel. The 176-bp PCR products $(10 \mu \mathrm{l})$ were digested overnight at $55^{\circ} \mathrm{C}$ with 5 units of BsmA1 restriction enzyme. The detection of the different alleles was carried out by horizontal ethidium bromide $4 \%$ agarose gel electrophoresis, along with a 100-bp DNA ladder. Genotypes were determined as homozygous for the wild type allele (Ile/Ile; 176 bp), heterozygous (Ile/Val; 176, 91, 85 bp) or homozygous for the mutant allele (Val/Val; 91 , $85 \mathrm{bp}$ ).

\section{Statistical analyses}

All statistical analyses were performed using EpiInfo version 6. Chi-square test was used to determine if there are any significant differences in polymorphism frequencies in the cancer cases compared with the control population. Statistics were calculated using $95 \%$ confidence intervals ( $\mathrm{p}<0.05$ significant).

\section{Results}

PCR-based genotyping assay was used to examine a GST-pi polymorphism in breast carcinoma susceptibility. The genotypic results of GST-pi are presented in Table II and Fig. 1. Our results showed no genotype effect with GST-pi genotype. Among breast cancer patients, $58 \%$ were homozygous for the wild type allele (Ile/Ile), $40 \%$ were heterozygous (Ile/Val) and $2 \%$ homozygous for the mutant allele (Val/Val). In the control group, $58 \%$ of the subjects were homozygous for the GST-pi wild type allele, $37.5 \%$ were heterozygous and $4.2 \%$ homozygous for the mutant allele (Table II). A slight difference was shown not to be significantly different. Overall, the results indicate that these GST-pi types do not appear to influence breast cancer susceptibility in the tested Jordanian female population. The observed percentages of GSTpi wild type and GST-pi mutant alleles were $77.1 \%$ and $22.9 \%$, respectively in the control population. In the 100 breast cancer population cases, the corresponding frequencies of GST-pi alleles were $78 \%$ and $22 \%$, for GST-pi wild type and mutant alleles, respectively (Table II).

On the subject of immunohistochemistry, there were 58\% GST-pi positive breast tumors; 38 and 20 cases of them were homozygous for the wild type allele (Ile/Ile) and heterozygous (Ile/Val) respectively. GST-pi protein was expressed in the cytoplasm, the nucleus, or both (Fig. 2). The proportion of GST-pi positive tumors was not significantly correlated with any genotype or histologic factors traditionally used for prognosis.

\section{Discussion}

Environmental carcinogen and reactive oxygen species can interact with DNA, mutate it and predispose to cancer [19]. An increasing number of studies have shown that the ability of individuals to detoxify potential carcinogens differs greatly [20]. Genes encoding enzymes involved in detoxification and metabolism of carcinogens can undergo muta- 
Table II. Genotype and allele percentage of the GSTP1 polymorphism

\begin{tabular}{|c|c|c|c|c|c|}
\hline \multirow[b]{2}{*}{ GENOTYPE } & \multicolumn{2}{|c|}{ Patients $(\mathrm{N}=100)$} & \multicolumn{2}{|c|}{ Control $(\mathrm{N}=48)$} & \multirow[t]{2}{*}{ P value } \\
\hline & NUMBER & PERCENTAGE & NUMBER & PERCENTAGE & \\
\hline Ile/Ile & 58 & $58 \%$ & 28 & $58.33 \%$ & 0.97 \\
\hline Ile/Val & 40 & $40 \%$ & 18 & $37.5 \%$ & \\
\hline $\mathrm{Val} / \mathrm{Val}$ & 2 & $2 \%$ & 2 & $4.16 \%$ & \\
\hline Allele & $\begin{array}{l}\text { NUMBER OF } \\
\text { ALLELES IN } 100 \\
\text { CANCER CASES } \\
\end{array}$ & $\begin{array}{c}\text { PERCENTAGE OF } \\
\text { ALLELES IN } 100 \\
\text { CANCER CASES } \\
\end{array}$ & $\begin{array}{c}\text { NUMBER OF } \\
\text { ALLELES IN } 48 \\
\text { CONTROLS } \\
\end{array}$ & $\begin{array}{c}\text { PERCENTAGE OF } \\
\text { ALLELES IN } 48 \\
\text { CONTROLS } \\
\end{array}$ & \\
\hline Ile & 156 & $78 \%$ & 74 & $77.1 \%$ & \\
\hline Val & 44 & $22 \%$ & 22 & $22.9 \%$ & \\
\hline
\end{tabular}

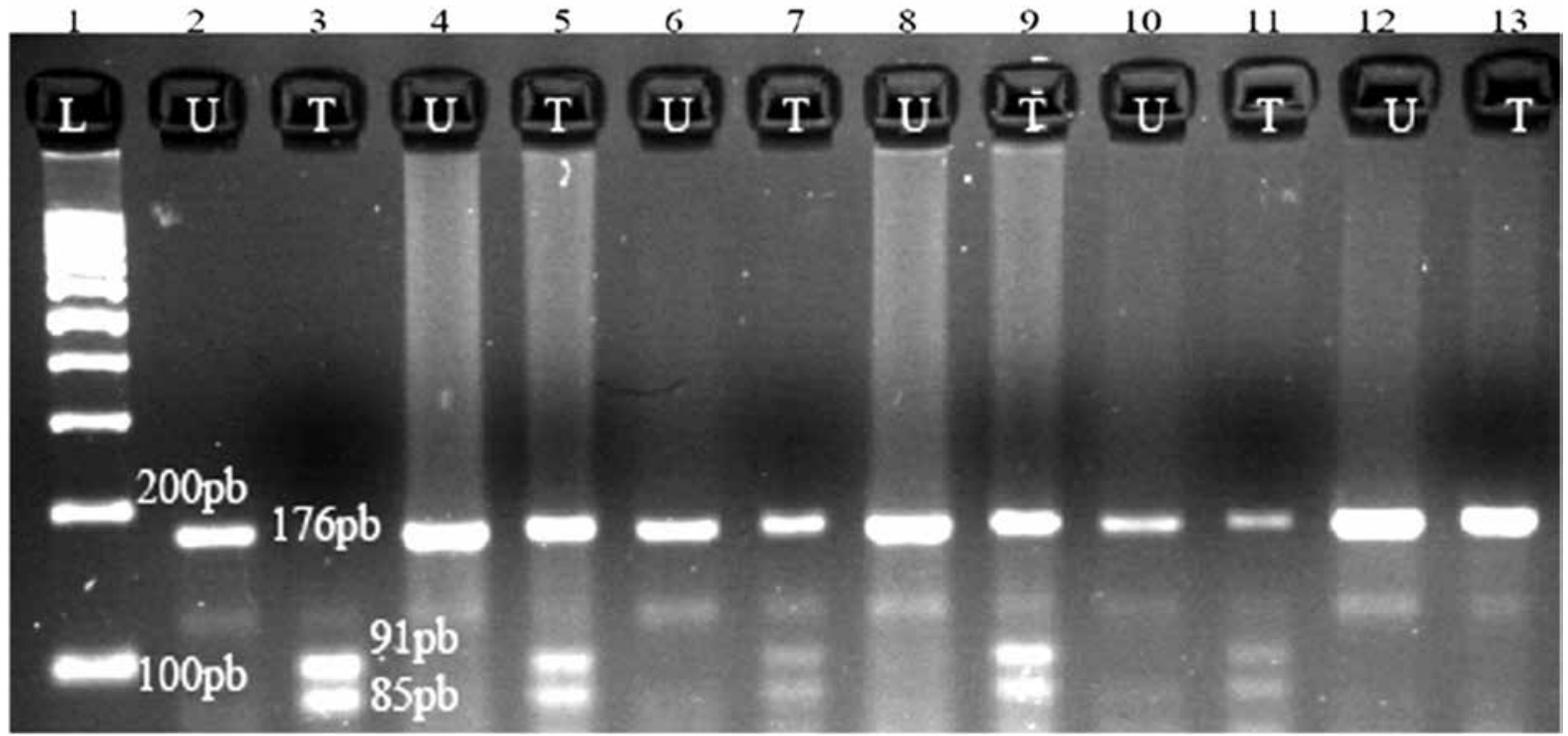

Fig. 1. Gel electrophoresis of GSTP1 RFLP results. Lane 2, 4, 6, 8, 10, 12 undigested samples, lane 3, 5, 7, 9, 11, 13 digested sample with BsmA1



Fig. 2. Cytoplasmic and nuclear immunohistochemical staining of GST-pi enzyme in malignant glandular epithelium of the breast. Magnification $20 \times$ tion leading to different levels of enzyme activity. Genetic polymorphisms in these genes are hence a factor involved in cancer susceptibility [5, 15]. Glutathione-S-transferases are phase II detoxification enzymes involved in the metabolism of a wide verity of potential carcinogens. The GST-pi variant genotype was seen in increased numbers of tumors of the kidney, bladder, pancreas and lung [21-23]. Millar et al. (1999) showed that the mutated enzyme (valine genotype) has lowered activity toward its substrate. The GST-pi polymorphism results in an amino acid change from isoleucine (wild type) to a valine (variant); this amino acid substitution occurs in the active site of the enzyme, which introduces conformational changes, due to the bulky properties of the valine side chain. Therefore, it is reasonable to speculate that a carcinogen metabolizing enzymes with lower activity could be associated with an elevated risk of developing cancer. However, to date, the po- 
tential association between genetic polymorphisms of GST-pi and breast carcinoma is still somewhat controversial and may vary from population to population [15-18, 25-31].

In the present study, GST-pi overexpression was detected in $58 \%$ of the examined breast cancer tissues. This finding is similar to that reported in Caucasian populations [32-34]. The absence of GST-pi protein in the remaining homozygous wild type allele breast tumors could be due to epigenetic modification such as DNA methylation and chromatin remodeling.

The statistical analysis of the presence of mutant allele showed no significant relationship between homozygous mutants and/or the heterozygous mutant and increased risk of breast cancer (Table II). The GST-pi wild type allele was present in $78 \%$ of the cancer samples, and in $77.1 \%$ of the control samples. Hence, the isoleucine allele does not appear to have a protective effect against breast cancer development. On the other hand, the mutant allele was present in $42 \%$ of breast cancer cases, and in $41.7 \%$ of controls. These results indicate that there is no correlation between the presence of the mutant allele and increased risk of breast cancer. This suggests that the mutant allele is randomly distributed in cancer and control cases. Our results are in harmony with the findings of many other reports such as those of Vogl et al. (2004) [35], and Unlu et al. (2008) [36]. 58.3\% of the controls of the present study showed homozygosity for the GST-pi wild type allele, which was comparable to $56 \%, 39 \%$, and $64.3 \%$ previously reported for a female control population from France, Southern Taiwan, and Norway respectively [37-39].

The results we report show a lack of association between the valine allele and/or variant genotype and sporadic breast carcinoma development. Similar$\mathrm{ly}$, the frequencies of carriers of the isoleucine allele were not different between the populations. Hence, in this population the isoleucine allele does not appear to have a protective effect against breast carcinoma development. The results of the current study have shown that the genotype GST-pi alone is not involved in breast carcinoma development, but this does not exclude interactions between genes and possible combinations of genotypes.

\section{Acknowledgements}

The author is grateful to Dr. Jamil Alalami, Mohamad Alotoom and Nidal Ganim for excellent technical assistance.

The author declares no conflict of interest. Supported by grant 54/2007 from Jordan University of Science and Technology, Irbid, Jordan.

\section{References}

1. Jordan Ministry of Health, http://www.moh.gov.jo/MOH/ Files/Publication/MINISTRY\%20OF\%20HEALTH.pdf

2. Ng EH, Gao F, Ji CY, et al. Risk factors for breast carcinoma in Singaporean Chinese women: the role of central obesity. Cancer 1997; 80: 725-731.

3. Jones KA, Brown MA, Soloman E. Molecular genetics of sporadic and familial breast cancer. Cancer Surv 1995; 25: 315334

4. Deakin M, Elder J, Hendrickse C, et al. Glutathione S-transferase GSTT1 genotypes and susceptibility to cancer: studies of interactions with GSTM1 in lung, oral, gastric and colorectal cancers. Carcinogenesis 1996; 17: 881-884.

5.Zhong S, Wyllie AH, Barnes D, et al. Relationship between the GSTM1 genetic polymorphism and susceptibility to bladder, breast and colon cancer. Carcinogenesis 1993; 14: 18211824.

6. Zhang P, Liu S, Shan S, et al. Modular mutagenesis of exons 1,2 , and 8 of a glutathione S-transferase from the mu class. Mechanistic and structural consequences for chimeras of isoenzyme 3-3. Biochemistry 1992; 31: 10185-10193.

7. Ryberg D, Skaug V, Hewer A, et al. Genotypes of glutathione transferase $\mathrm{M} 1$ and $\mathrm{P} 1$ and their significance for lung DNA adduct levels and cancer risk. Carcinogenesis 1997; 18: 12851289.

8. Forrester LM, Hayes JD, Millis R, et al. Expression of glutathione S-transferases and cytochrome P450 in normal and tumor breast tissue. Carcinogenesis 1990; 11: 2163-2170.

9. Shea TC, Claflin G, Comstock KE, et al. Glutathione transferase activity and isoenzyme composition in primary human breast cancers. Cancer Res 1990; 50: 6848-6853.

10. Albin N, Massaad L, Toussaint C, et al. Main drug-metabolizing enzyme systems in human breast tumors and peritumoral tissues. Cancer Res 1993; 53: 3541-3546.

11.Zimniak P, Nanduri B, Pikula S, et al. Naturally occurring human glutathione S-transferase GST-PI -1 isoforms with isoleucine and valine in position 105 differ in enzymatic properties. Eur J Biochem 1994; 224: 893-899.

12. Board PG, Webb GC, Coggan M. Isolation of a cDNA clone and localization of the human glutathione S-transferase 3 genes to chromosome bands $11 \mathrm{q} 13$ and 12q13-14. Ann Hum Genet 1989; 53: 205-213.

13. Ali-Osman F, Akande O, Antoun G, et al. Molecular cloning, characterization, and expression in Escherichia coli of fulllength cDNAs of three human glutathione S-transferase Pi gene variants. Evidence for differential catalytic activity of the encoded proteins. J Biol Chem 1997; 272: 10004-10012.

14. Sundberg K, Johansson AS, Stenberg G, et al. Differences in the catalytic efficiencies of allelic variants of glutathione transferase P1-1 towards carcinogenic diol epoxides of polycyclic aromatic hydrocarbons. Carcinogenesis 1998; 19: 433-436.

15. Helzlsouer KJ, Selmin O, Huang HY, et al. Association between glutathione S-transferase M1, P1, and T1 genetic polymorphisms and development of breast cancer. J Natl Cancer Inst 1998; 90: 512-518.

16. Millikan R, Pittman G, Tse CK, et al. Glutathione S-transferase M1, T1, and P1 and breast cancer. Cancer Epidemiol Biomarkers Prev 2000; 9: 567-573.

17. Mitrunen K, Jourenkova N, Kataja V, et al. Glutathione S-transferase M1, M3, P1, and T1 genetic polymorphisms and susceptibility to breast cancer. Cancer Epidemiol Biomarkers Prev 2001; 10: 229-236.

18. Gudmundsdottir K, Tryggvadottir L, Eyfjord JE. GSTM1, GSTT1, and GST-PI genotypes in relation to breast cancer risk and frequency of mutations in the p53 gene. Cancer Epidemiol Biomarkers Prev 2001; 10: 1169-1173.

19. Pemble S, Schroeder KR, Spencer SR, et al. Human glutathione S-transferase Theta (GSTT1): cDNA cloning and the 
characterization of a genetic polymorphism, Biochem J 1994 300: $271-276$

20. Strange RC, Matharoo B, Faulder GC, et al. The human glutathione S-transferase: a case-control study of the incidence of the GST1 0 phenotype in patients with adenocarcinoma, Carcinogenesis 1991; 12: 25-28.

21. Simic T, Savic-Radojevic A, Pljesa-Ercegovac M, et al. Glutathione S-transferases in kidney and urinary bladder tumors. Nat Rev Urol 2009; 6: 281-289.

22. Vrana D, Pikhart H, Mohelnikova-Duchonova B, et al. The association between glutathione S-transferase gene polymorphisms and pancreatic cancer in a central European Slavonic population. Mutat Res 2009; 680: 78-81

23. To-Figueras J. Gene M. Gomez-Catalan J, et al. Genetic polymorphism of glutathione S-transferase P1 gene and lung cancer risk. Cancer Causes Control 1999; 10: 65-70.

24. Millar DS, Ow KK, Paul CL, et al. Detailed methylation analysis of the glutathione S-transferase pi (GST-PI ) gene in prostate cancer. Oncogene 1999; 18: 1313-1324.

25. Sreenath AS, Kumar KR, Reddy GV, et al. Evidence for the association of synaptotagmin with glutathione S-transferases: implications for a novel function in human breast cancer. Clin Biochem 2005; 38: 436-443.

26. Unlü A, Ates NA, Tamer L, et al. Relation of glutathione S-transferase T1, M1 and P1 genotypes and breast cancer risk. Cell Biochem Funct 2008; 26: 643-647.

27. Saxena A, Dhillon VS, Raish M, et al. Detection and relevance of germline genetic polymorphisms in glutathione S-transferases (GSTs) in breast cancer patients from northern Indian population. Breast Cancer Res Treat 2009; 115: 537-543.

28. Pongtheerat T, Pakdeethai S, Purisa W, et al. Promoter methylation and genetic polymorphism of glutathione S-transferase P1 gene (GSTP1) in Thai breast-cancer patients. Asian Pac J Cancer Prev 2011; 12: 2731-4

29. Aguiar ES, Giacomazzi J, Schmidt AV, et al. GSTM1, GSTT1, and GSTP1 polymorphisms, breast cancer risk factors and mammographic density in women submitted to breast cancer screening. Rev Bras Epidemiol 2012; 15: 246-255.

30. Ramalhinho AC, Fonseca-Moutinho JA, Breitenfeld L. Glutathione S-transferase M1, T1, and P1 genotypes and breast cancer risk: a study in a Portuguese population. Mol Cell Biochem 2011; 355: 265-271.

31. Ramalhinho AC, Fonseca-Moutinho JA, Breitenfeld Granadeiro LA. Positive Association of Polymorphisms in Estrogen Biosynthesis Gene, CYP19A1, and Metabolism, GST, in Breast Cancer Susceptibility. DNA Cell Biol 2012; 31: 1100-1106.

32. Frierson HF, Gaffey MJ, Meredith SD et al. Immunohistochemical staining and Southern blot hybridization for glutathione $\mathrm{S}$-transferase $\mathrm{p}$ in mammary infiltrating ductal carcinoma. Modern Pathol 1995; 8: 643-647.

33. Silverstrini R, Veneroni S, Benini E, et al. Expression of p53, glutathione S-transferase-pi, and $\mathrm{Bcl}-2$ proteins and benefit from adjuvant radiotherapy in breast cancer. J Natl Cancer Inst 1997; 89: 639-645.

34. Huang J, Tan PH, Thiyagarajan J, et al. Prognostic Significance of Glutathione S-Transferase-Pi in Invasive Breast Cancer. Mod Pathol 2003; 16: 558-565.

35. Vogl FD, Taioli E, Maugard C, et al. Glutathione S-transferases M1, T1, and P1 and breast cancer: a pooled analysis. Cancer Epidemiol Biomarkers Prev 2004; 13: 1473-1479.

36. Unlü A, Ates NA, Tamer L, et al. Relation of glutathione S-transferase T1, M1 and P1 genotypes and breast cancer risk. Cell Biochem Funct 2008; 26: 643-647.

37. Maugard CM, Charrier J, Pitard A, et al. Genetic polymorphism at the glutathione S-transferase (GST) P1 locus is a breast cancer risk modifier. Int J Cancer 2001; 91: 334-339.
38. Chang TW, Wang SM, Guo YL, et al. Glutathione S-transferase polymorphisms associated with risk of breast cancer in southern Taiwan. Breast 2006; 15: 754-761.

39. Edvardsen H, Kristensen VN, Grenaker Alnaes GI, et al. Germline glutathione Stransferase variants in breasr cancer: Relation to diagnosis and cutaneous long-term adverse effects after two fractionation patterns of radiotherapy. Int J Radiat Oncol Biol Phys 2007; 67: 1163-1171.

\section{Address for correspondence}

Dr. Mohammad Nidal Khabaz

Pathology Department

Faculty of Medicne

King Abdulaziz University (Rabigh Branch)

Jeddah, Arabia Saudi

e-mail:nkhabaz@yahoo.com.uk 